\title{
Pembinaan kelompok petani budidaya melalui kegiatan aplikasi teknik probiotik dan pembuatan pakan berbasis bahan lokal pada Budidaya Ikan Lele di Kelurahan Tangkerang Utara Kecamatan Bukit Raya Kota Pekanbaru
}

\author{
Usman M Tang*, Niken Ayu Pamukas, Adelina, Iesje Lukistyowati, \& Mulyadi \\ Fakultas Perikanan dan Kelautan, Universitas Riau \\ *usman_mt@yahoo.co.id
}

\begin{abstract}
Abstrak. Mata pencaharian masyarakat Kelurahan Tangkerang Utara adalah; di bidang pertanian, perkebunan, peternakan, wiraswasta dan perikanan. Pada bidang perikanan terdapat dua kelompok pembudidaya ikan (POKDAKAN) di kelurahan ini, yaitu; POKDAKAN Cahaya Utara Mandiri dan Dolphin Farm, yang melakukan usaha budidaya ikan pada kolam-kolam tanah dan semen serta keramba. Permasalahan utama yang dihadapi POKDAKAN adalah terbatasnya ketersediaan air yang diperuntukkan untuk budidaya ikan dan kualitas air yang kurang sesuai untuk pertumbuhan ikan lele. Melalui program desa binaan yang dilakukan ini, diberikan ilmu dan teknologi tentang teknik aplikasi probiotik pada media budidaya untuk meningkatkan kualitas air dan meminimalkan penggunaan air. Metode yang digunakan dalam kegiatan pengabdian Desa Binaan ini adalah metode ceramah, diskusi dan praktek langsung di kolam-kolam milik anggota POKDAKAN. Hasil evaluasi terhadap 23 orang peserta penyuluhan menunjukkan 20 orang $(86,96 \%)$ belum pernah mengenal tentang aplikasi probiotik pada media budidaya, sedangkan 2 orang $(8,70 \%)$ telah mengetahui tentang aplikasi probiotik serta 1 orang $(4,34 \%)$ telah mengaplikasikannya pada kolam budidaya ikan lele. Setelah mengikuti kegiatan pelatihan ini terjadi peningkatan pengetahuan tentang aplikasi probiotik ini sebesar $86,96 \%$. Sementara itu 22 orang peserta telah memahami tentang dosis dan frekuensi pemberian pakan, dan seluruh peserta telah mengetahui bagaimana criteria benih ikan yang sehat. Penilaian mitra terhadap pelaksanaan kegiatan ini adalah: 52,17 sangat setuju aplikasi probiotik ini dapat dilakukan secara mandiri; 52,17\% sangat setuju aplikasi probiotik dapat meningkatkan kualitas air; 60,87\% sangat setuju dapat menjadi alternatif mata pencaharian; $65,22 \%$ sangat setuju dapat mempercepat masa pemeliharaan.
\end{abstract}

Kata kunci: probiotik, pertumbuhan, kualitas air, Clariasbatrachus

\begin{abstract}
The livelihoods of the people of Tangkerang Utara Village are; in agriculture, plantation, animal husbandry, self-employment and fisheries. In the fisheries sector, there are two groups of fish cultivators (POKDAKAN) in this kelurahan, namely; POKDAKAN Cahaya Utara Mandiri and Dolphin Farm, which conduct fish farming in soil and cement ponds and cages. The main problems faced by POKDAKAN are the limited availability of water intended for fish cultivation and the wate rquality that is not suitable for catfish growth. Throught his program of guided villages, knowledge and technology is given on the technique of applying probiotics to cultivation media to improve wate rquality and minimize water use. The method used in the community service activities of the Assisted Village is the method of lecturing, discussion and direct practice in the pools owned by POKDAKAN members. The results of the evaluation of 23 extension participants showed that 20 people (86.96\%) had never known about the application of probiotics in cultivation media, while 2 people $(8.70 \%)$ had known about the application of probiotics and 1 person (4.34\%) had apply it to catfish farming ponds. After participating in this training activity, there was an increase in knowledge about the application of this probiotic by $69.57 \%$. Meanwhile, 22 participants understood the dosage and frequency of feeding, and all participants had already known the criteria for healthy fish seeds. The partners' assessments of the implementation of this activity are: 52.17 strongly agree that this probiotic application can be done independently; $52.17 \%$ strongly agree that probiotic applications can improve water quality; $60.87 \%$ strongly agreed that it could be an alternative livelihood; $65.22 \%$ strongly agree to speed up the maintenance period.
\end{abstract}

Keywords: probiotics, growth, water quality, Clariasgariepinus 
To cite this article: M. T. Usman., N. A. Pamukas., Adelina., I. Lukistyowati., \& Mulyadi. 2020. Pembinaan kelompok petani budidaya melalui kegiatan aplikasi teknik probiotik dan pembuatan pakan berbasis bahan lokal pada Budidaya Ikan Lele di Kelurahan Tangkerang Utara Kecamatan Bukit Raya Kota Pekanbaru. Unri Conference Series: Community Engagement 2: 177-183. https://doi.org/10.31258/unricsce.2.177-183

(C) 2020 Authors

Peer-review under responsibility of the organizing committee of Seminar Nasional Pemberdayaan Masyarakat 2020

\section{PENDAHULUAN}

Tangkerang Utara merupakan salah satu kelurahan di wilayah Kecamatan Bukit Raya, Kota Pekanbaru. Kelurahan ini berdiri pada tahun 1993 yang terdiri dari 16 Rukun Warga (RW) dan 62 RukunTetangga (RT). Kelurahan Tangkerang Utara memiliki luas wilayah \pm 435 ha dengan jumlah penduduk sebanyak 22.480 jiwa atau 6.129 KK. Jarak antara Kelurahan Tangkerang Utara dengan ibu kota kecamatan 2 km, dengan ibu kota kabupaten/kota 2 km dan jarak dengan ibu kota provinsi 6 km (Badan Pusat Statistik Kota Pekanbaru, 2018).

Kelurahan Tangkerang Utara merupakan daerah dataran rendah dengan sedikit perbukitan yang berbatasan langsung dengan wilayah Tangkerang Timur, Kecamatan Sail, Jl. Harapan Raya dan Jl. Jendral Sudirman. Masyarakat KelurahanTangkerang Utara memiliki mata pencaharian yang bervariasi, yaitu dalam bidang: pertanian, perkebunan, peternakan, wiraswasta dan perikanan. Pada bidang perikanan terdapat 2 POKDAKAN Cahaya Utara Mandiri dan Dolphin Farm. POKDAKAN ini melakukan budidaya ikan di kolam tanah dan semen, serta keramba. Jenis-jenis ikan yang dipelihara adalah ikan lele dumbo (Clarias gariepinus Burcheel) dan ikan patin (Pangasius sutchii). Permintaan ikan lele yang semakin meningkat, mendorong dilakukannya budidaya intensif untuk memenuhi permintaan konsumen terhadap ikan lele. Budidaya intensif menuntut dilakukannya budidaya dalam padat tebar yang tinggi dan jumlah pakan yang banyak, sehingga menyebabkan sisa pakan dan feses meningkat yang akhirnya dapat meningkatkan konsentrasi amoniak di media budidaya.

Aplikasi probiotik pada media budidaya melalui teknik bioflok (Putra et al., 2020) dan teknik boster (Pamukas et al, 2020) terbukti dapat mengatasi permasalahan kualitas air khususnya dalam pengendalian total amonia nitrogen pada sistem budidaya (Avnimelech, 2009, Irianto, 2003; Mansyur and Tangko, 2008; Putra et al., 2020). Disamping itu juga aplikasi probiotik meningkatkan konsentrasi nitrat sehingga meningkatkan kelimpahan plankton yang merupakan pakan alami bagi ikan dan akhirnya menurunkan biaya pembelian pakan komersil (Lakshmanan dan Soundarapandian (2008); Pamukas et al, 2020). Menurut Poernomo (2004) ada beberapa alasan penggunaan bakteri probiotik untuk perbaikan kualitas air diantaranya dapat mempercepat penguraian bahan organik yang berasal dari feses ikan, sisa pakan dan bangkai plankton di dasar tambak.

Permasalahan pembudidaya ikan di Kelurahan Tangkerang Utara yang berhasil diidentifikasi pada saat melakukan kegiatan adalah: tingginya tingkat kematian ikan pada saat pembesaran karena ikan terserang penyakit, pengelolaan kolam yang buruk dan rendahnya $\mathrm{pH}$ sumber air yang digunakan untuk budidaya, sehingga menyebabkan media pemeliharaan miskin unsur hara dan kandungan bahan organiknya tinggi. Permasalah tersebut dapat diatasi dengan aplikasi probiotik, namun anggota POKDAKAN di kelurahan ini belum mengetahui dan menguasai pengetahuan mengenai teknik aplikasi probiotik pada media budidaya. Menurut Rusliadi et al. (2018) hal tersebut disebabkan keterbatasan ilmu pengetahuan dan keterampilan yang umumnya dimiliki oleh petani ikan di pedesaan. Untuk itu perlu dilakukan kegiatan penyuluhan tentang teknologi aplikasi probiotik pada media budidaya ikan lele di kelurahan ini meliputi pengetahuan praktis dan keterampilan yang dapat dilakukan secara mandiri. Dengan dikuasai dan diterapkannya pengetahuan tentang teknik aplikasi probiotik pada media budidaya, maka diharapkan anggota POKDAKAN dapat menekan biaya produksi terutama pada pembelian pakan, serta meningkatkan produksi ikan lele di kelurahan Tangkerang Utara ini.

Kegiatan Program Desa Binaan yang dilakukan Tim Lembaga Penelitian dan Pengabdian Universitas Riau terhadap pembudidaya ikan di Kelurahan Tangkerang Utara bertujuan untuk menambah pengetahuan dan keterampilan kepada pembudidaya ikan tentang penggunaan probiotik untuk meningkatkan kualitas air sebagai media pemeliharaan ikan, pertumbuhan dan kelulushidupan ikan.

\section{METODE PENERAPAN}

Kegiatan pembinaan kelompok petani budidaya melalui kegiatan aplikasi teknik probiotik dan pembuatan pakan berbasis bahan lokal pada budidaya ikan lele di Kelurahan Tangkerang Utara ini dilakukan selama 6 
bulan, mulai dari pendekatan kepada masyarakat sasaran sampai dengan pelaksanaan kegiatan. Metode penerapan IPTEKS kepada mitra dilakukan selama 3 tahun, tahun pertama kegiatan yang sudah dilakukan adalah: Memberikan penyuluhan mengenai teknik aplikasi probiotik, teknik pembuatan pakan dan membuat kolam percontohan berupa 3 unit kolam terpal lengkap dengan instalasi air, listrik dan aerasi.

Kegiatan yang dilakukan pada tahun kedua in iadalah: 1). Peningkatan produksi ikan melalui aplikasi inovasi teknologi perikanan yang didapatkan pada tahun pertama pada skala massal, yaitu dengan melakukan aplikasi probiotik pada kolam-kolam yang dimiliki pembudidaya ikan di kelurahan Tangkerang Utara; 2). Peningkatan pendapatan pembudidaya ikan melalui teknik pengolahan hasil panen ikan lele, sehingga hasil panen dapat dipasarkan dengan harga yang lebih tinggi dibandingkan harga ikan segar. Sedangkan rencana kegiatan yang akan dilakukan pada tahun ketiga adalah: Peningkatan keterampilan pembudidaya ikan dalam penanganan pasca panen produk hasil budidaya ikan dan pengemasan sampai pemasarannya.

Kegiatan yang dilakukan pada tahun kedua ini dimulai dengan melakukan pertemuan dan diskusi dengan mitra tentang rencana kegiatan yang akan dilaksanakan, melibatkan Lurah, perangkat kelurahan, Ketua POKDAKAN Dolphin Farm dan Cahaya Utara Mandiri. Kemudian dilanjutkan dengan penyampaian materi dan praktek di kolammilik POKDAKAN Dolphin Farm dan Cahaya Utara Mandiri. Materi dan praktek yang disampaikan meliputi : 1). Intensifikasi teknik budidaya ikan lele di kolam, teknik pemilihan benih unggul, cara penentuan padat tebar yang tepat serta penentuan dosis probiotik. 2). Jenis-jenis probiotik yang dapat diaplikasikan pada kolam budidaya untuk mempercepat penguraian bahan organik. 3). Pemilihan bahan baku pakan ikan yang murah, berbasis lokal dan ramah lingkungan dan analisa biaya. Setelah penyampaian materi dilakukan prakteka plikasi probiotik pada kolam budidaya ikan lele milik anggota POKDAKAN.

Untuk menilai ketercapaian tujuan kegiatan, dilakukan evaluasi. Jenis evaluasi yang dilakukan adalah: 1) Evaluasi Proses dan 2) Evaluasi Peningkatan Pengetahuan. Evaluasi proses dilakukan selama proses penyuluhan berlangsung, mulai dari penyajian materi (teori) sampai kegiatan praktek. Disini dilihat keseriusan peserta mengikuti serangkaian kegiatan tersebut dan diskusi-diskusi yang berkembang. Evaluasi peningkatan pengetahuan dilakukan dengan memberikan pre test dan post test. Hasil dari pre test dibandingkan dengan post test, apakah ada penambahan pengetahuan atau sebaliknya. Peningkatan pengetahuan ditampilkan dalam bentuk persentase (\%).

Masyarakat yang dijadikan sasaran kegiatan sekaligus Mitra Program Desa Binaan di Kelurahan Tangkerang Utara adalah 23 orang pembudidaya ikan yang berada dalam wadah Kelompok Pembudidaya Ikan (POKDAKAN) Cahaya Utara Mandiri dan Dolphin Farm. Lokasi POKDAKAN Cahaya Utara Mandiri bertempat di Jalan Banda Aceh RT 02 RW 14 KelurahanTangkerang Utara Kecamatan Bukit Raya Kota Pekanbaru. POKDAKAN ini merupakan kelompok pembudidaya ikan yang sudah mempunyai badan hokum dengan nomor AHU0000085.AH.01.07.TAHUN 2019.

Anggota POKDAKAN Cahaya Utara Mandiri menjadikan budidaya ikan sebagai mata pencaharian sampingan, sedangkan mata pencaharian utamanya adalah pedagang, aparatur sipil negara, karayawan perusahaan swasta dan wirausaha. Pembudidaya ikan melakukan budidaya ikan menggunakan kolam semi permanen berukuran $5 \times 6 \mathrm{~m}$ sampai $10 \times 15 \mathrm{~m}$. Air sebagai media pemelliharaan ikan berasal dari sumur bor. Jenis ikan yang mereka pelihara adalah ikan nila (Oreochromis niloticus), patin (Pangasius hypopthalmus), gurami (Osphronemus gourami) dan lele dumbo (Clarias gariepinus).

\section{HASIL DAN KETERCAPAIAN}

\section{Potensi pengembangan (Pemberdayaan) masyarakat}

Pesatnya perkembangan usaha kuliner, khususnya usaha pecel lele di Kota Pekanbaru, menyebabkan tingginya permintaan pasar terhadap komoditas ikan lele. Permasalahan utama yang dihadapi anggota POKDAKAN Cahaya Utara Mandiri adalah tingginya harga pakan dan rendahnya harga ikan saat hasil panen banyak di pasaran. Tingginya harga pakan dapat diatasi dengan melakukan aplikasi probiotik pada kolam budidaya. Penambahan probiotik pada media budidaya bertujuan untuk meningkatkan pakan alami, sehingga penggunaan pakan buatan dapat dikurangi dan biaya pembelian pakan menjadi rendah.

Berdasarkan penjabaran di atas kegiatan aplikasi teknik probiotik pada kolam budidaya yang dilakukan di KelurahanTangkerang Utara merupakan suatu kegiatan usaha yang memiliki prospek yang baik dan layak untuk dikembangkan ditinjau dari aspek pasar, aspek teknis dan aspek finansial. Ditinjau dari aspek pasar usaha budidaya lele ini layak karena potensi pasar yang besar. Ditinjau dari aspek teknis usaha budidaya lele ini dapat dikembangkan karena ketersediaan bahan-bahan pembuat kolam berbasis probiotik mudah didapat dan harganya terjangkau. Tingkat teknologi yang digunakan umumnya juga masih sederhana sehingga dapat 
diterapkan dalam pengelolaan usaha di tingkat petani, kemudian sarana dan prasarana pendukung secara umum mudah didapat atau bisa dimodifikasi, dan nilai tambah produk dapat ditingkatkan melalui teknis budidaya yang dapat diterapkan di tingkat petani. Hasil survey dan wawancara dengan penduduk setempat juga menunjukkan bahwa mereka berminat untuk melakukan budidaya ikan lele dengan sistem budidaya menggunakan probiotik karena dapat diterapkan di lahan yang relatif kecil atau di halaman rumah, hemat air dan biaya pembelian pakan komersil dapat ditekan.

\section{Solusi pengembangan (Pemberdayaan) masyarakat}

Solusi yang dapat dilakukan agar usaha budidaya ikan di Tangkerang Utara dapat diterapkan dan berkelanjutan, serta produksinya dapat ditingkatkan untuk memenuhi permintaan pasar adalah dengan cara melakukan budidaya ikan dengan aplikasi teknik probiotik dan pembuatan pakan berbasis bahan lokal pada budidaya ikan lele. Kemudian memberi pakan ke ikan peliharaan dari hasil buatan sendiri dengan menggunakan bahan-bahan local seperti tepung biji karet, ampas tahu, ikan rucah dan lain-lain sehingga harganya relatif murah, menerapkan teknik pencegahan dan pengobatan penyakit ikan, serta pengolahan produk budidaya pasca panen untuk meningkatkan harga jualnya.

\section{Tingkat ketercapaian sarana program}

Kegiatan Program Desa Binaan di Kelurahan Tangkerang Utara dimulai dengan melakukan pertemuan dan diskusi pada bulan April 2020 dengan mitra (POKDAKAN Dolphin Farm dan Cahaya Utara Mandiri), kemudian dilanjutkan pada tanggal 7 Juli 2020 menandatangani surat kemitraan dan koordinasi mengenai kegiatan yang akan dilaksanakan, persiapan bahan dan alat yang dibutuhkan pada saat pelaksanaan kegiatan, jadwal dan lokasi yang akan dipilih sebagai kolam percontohan (Gambar 1).

Koordinasi juga dilakukan dengan perangkat Kelurahan, POKDAKAN Dolphin Farm dan Cahaya Utara Mandiri, mahasiswa KUKERTA terintegrasi dan Tim Pengabdian Kepada Masyarakat LPPM Universitas Riau, di kantor Kelurahan. Berdasarkan hasil pertemuan dengan Ibu Kepala Kelurahan Tangkerang Utara Bismiyati, S.H., ketua POKDAKAN Cahaya Utara Mandiri Burhan Budi dan ketua Dolphin Farm Suhendra, disepakati pelaksanaan kegiatan dilakukan pada bulanJ uli 2020, penyampaian materip raktek dilakukan pada salah satu rumah anggota POKDAKAN.

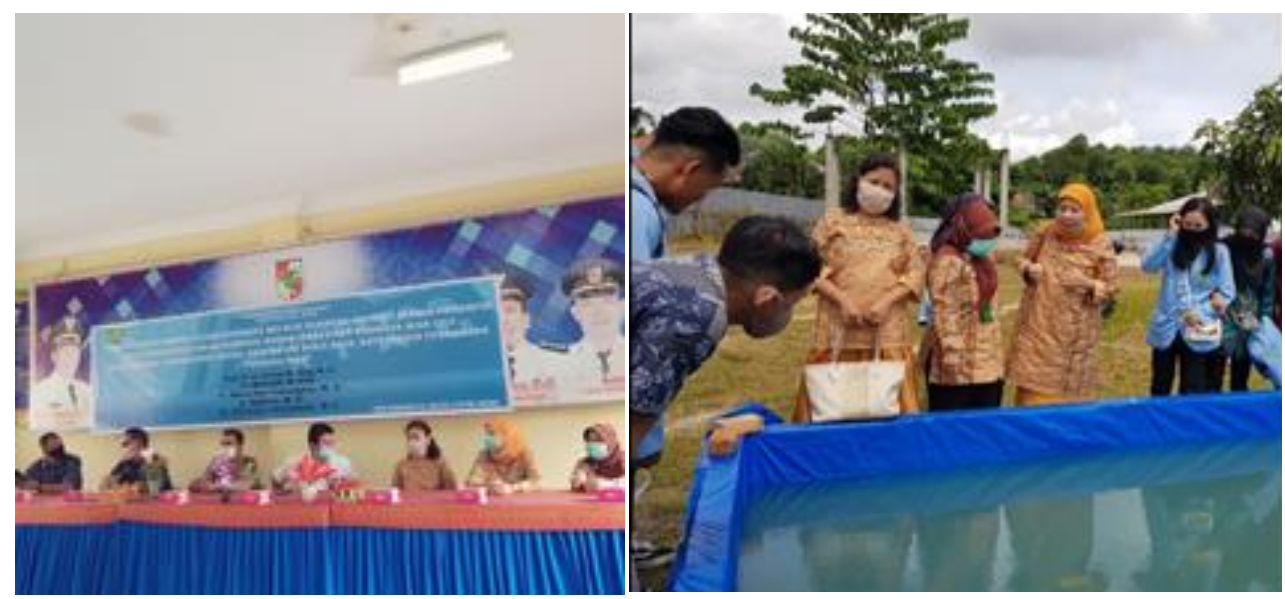

Gambar 1. Koordinasi TIM Desa Binaan dengan perangkat Desa Kelurahan Tangkerang Utara, POKDAKAN Cahaya Utara Mandiri dan Dolphin Farm.

Penyampaian materi dilakukan di unit usaha POKDAKAN Dolphin Farm (Gambar 2), penyajian materi penyuluhan diawali dengan pemberian kata sambutan oleh Sekretaris Lurah Tangkerang Utara Bapak Isnaini, S.Kep., kemudian pemaparan usaha budidaya ikan di Kelurahan Tangkerang Utara oleh ketua POKDAKAN Cahaya Utara Mandiri Burhan Budi dan ditutup pembacaan doa oleh coordinator kelompok mahasiswa KUKERTA terintegrasi. Pada kegiatan ini mahasiswa KUKERTA terintegrasi dilibatkan secara aktif. Pada saat penyampaian materi kepada peserta penyuluhan dibagikan modul yang memuat materi yang disampaikan, yaitu mengenai teknik budidaya ikan lele dengan aplikasi probiotik pada kolam budidaya, pemilihan bahan baku pakan ikan yang murah, berbasi slokal dan rama hlingkungan, jenis-jenis probiotik yang dapat diaplikasikan pada kolam budidaya untuk mempercepat penguraian baha norganik dan menekan konsentrasi 
amoniak dan teknik pencegahan dan engobatan penyakit ikan dengan menggunakan bahan fitofarmaka seperti bawang putih, kunyit, temulawak, sambiloto, daun jambu biji dan lain-lain.

Selama penyampaian materi, peserta penyuluhan juga diberi kesempatan untuk bertanya mengenai materi yang kurangd ipahami. Diskusi pada sesi ini berlangsung sangat baik, peserta penyuluhan antusias bertanya ke narasumber, karena materi yang disampaikan masih baru buat mereka.
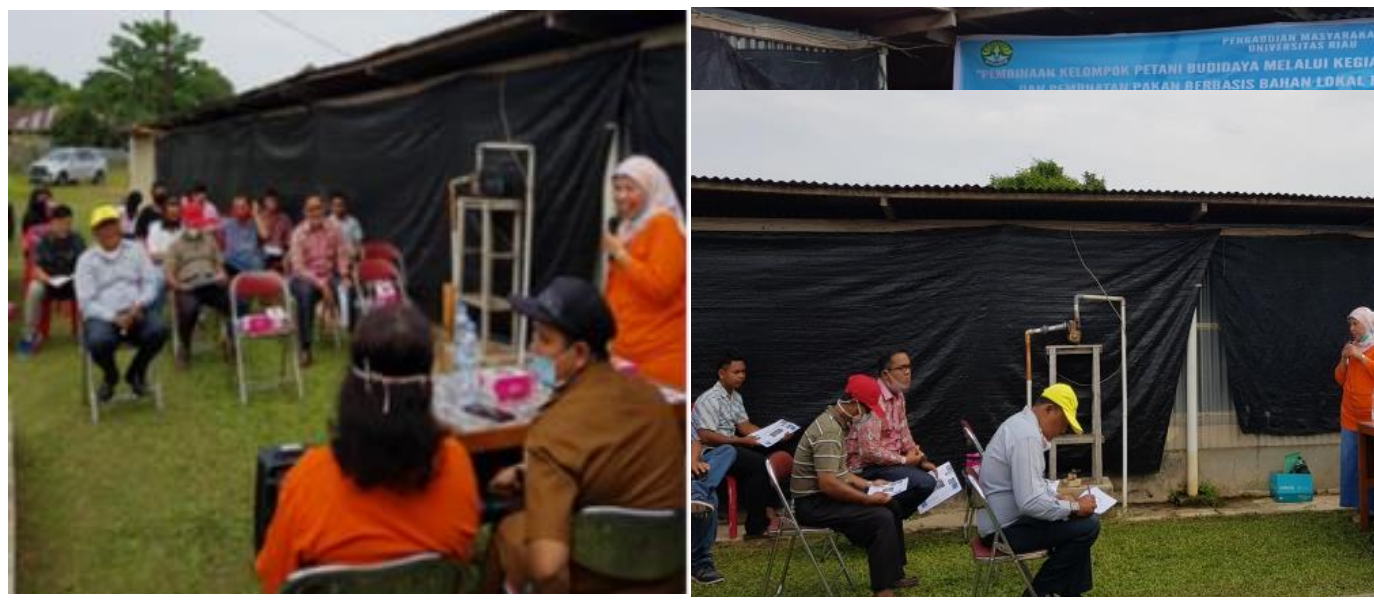

Gambar 2. Penyampaian materi penyuluhan oleh TIM Desa Binaan

Praktek aplikasi probiotik di kolam budidaya milik POKDAKAN Dolphin Farm, dilakukan secara aktif melibatkan anggota POKDAKAN dan TIM KUKERTA terintegrasi yang dibimbing oleh TIM Pengabdian Desa Binaan LPPM UNRI. Kegiatan dimulai dengan melakukan persiapan kolam, yaitu dengan cara meningkatkan $\mathrm{pH}$ airnya menjadi 7 dengan melakukan pengeringan kolam yang akan digunakan, pengangkatan lumpur dan pengapuran (Gambar 3). Kapur yang diberikan merupakan kapur dolomit. Sebanyak $200 \mathrm{gr} / \mathrm{m}^{3}$, kemudian ditambahkan garam krosok (non-iodium) $3 \mathrm{~kg} / \mathrm{m}^{3}$ air.
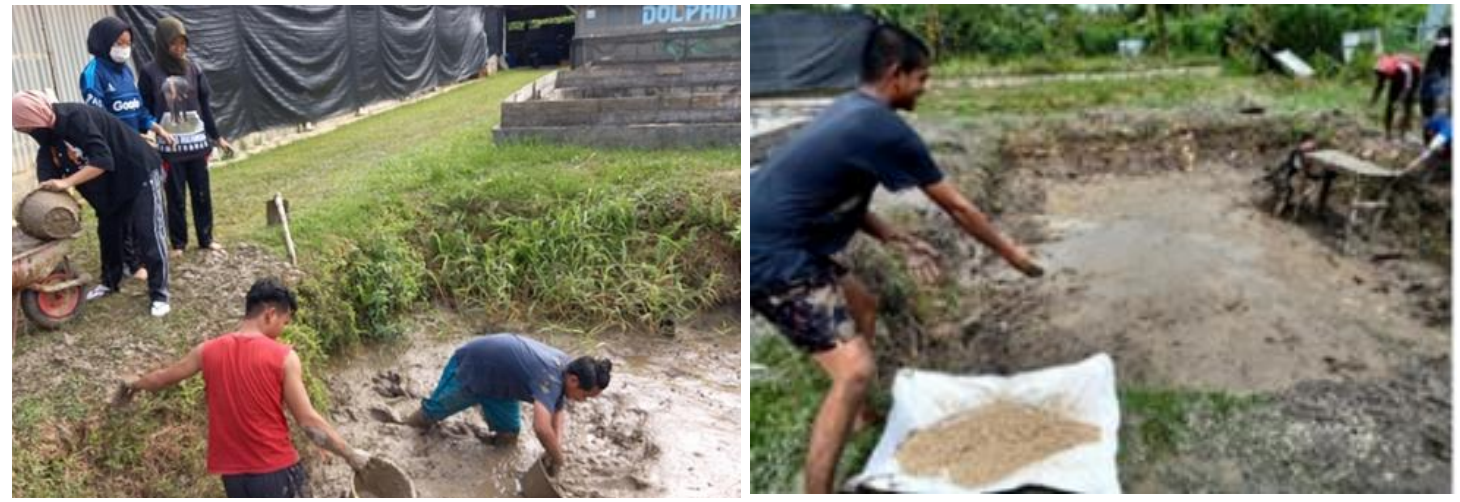

Gambar 3. Persiapan kolam oleh anggota POKDAKAN melibatkan mahasiswa KUKERTA terintegrasi untuk melakukan pelatihan di lapangan

Setelah pengapuran dilakukan praktek pembuatan starter probiotik dengan cara mencampurkan $20 \mathrm{~mL} / \mathrm{m}^{3}$ probiotik boster dan molase $450 \mathrm{~mL} / \mathrm{m}^{3}$ kedalam satu liter air, lalu dimasukan ke dalam masing-masing kolam pemeliharaan (Gambar 4). Malam harinya ditambahkan $100 \mathrm{gram} / \mathrm{m}^{3}$ kapur dolomit yang dilarutkan ke dalam satu liter air. Endapan kapur disisihkan sementara air kapur dicampurkan ke wadah. Wadah dibiarkan selama 7 hari sampai agregat flok terbentuk dengan ciri-ciri visual terlihat gumpalan-gumpalan berwarna putih dan perubahan warna air menjadi cokelat kekeruhan. Probiotik ditambahkan ke wadah setiap 7 hari dengan dosis yang sama (Putra et al., 2017). 

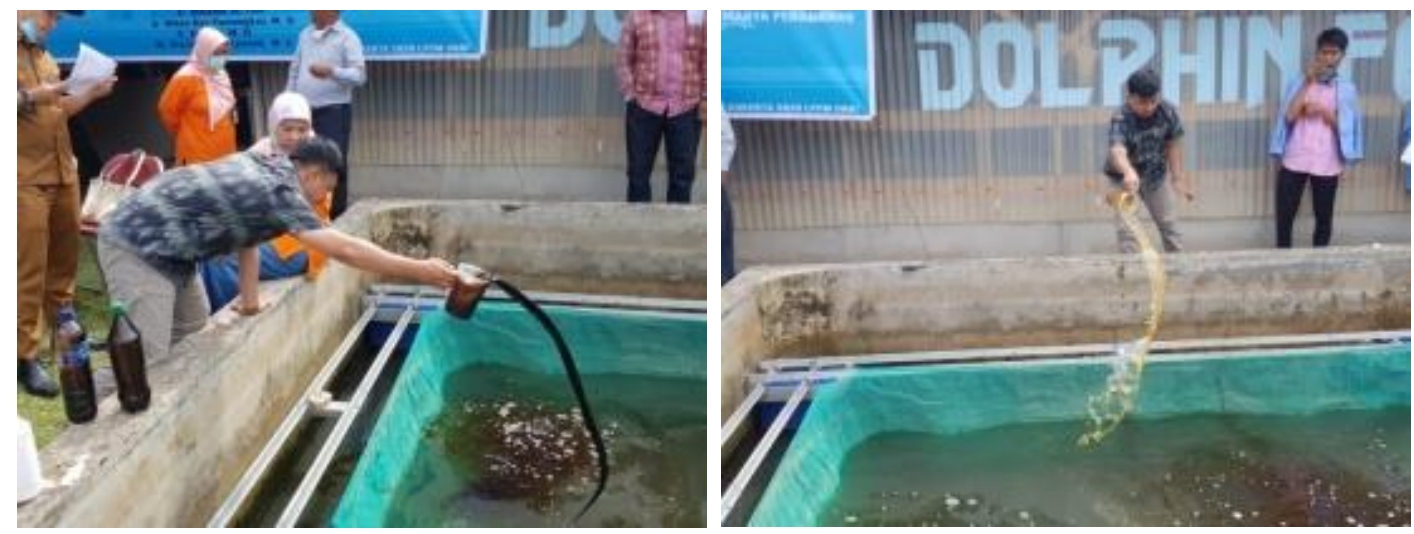

Gambar 4. Pembuatan starter probiotik dan pengaplikasiannya di kolam budidaya ikan lele milik POKDAKAN

Setelah 7 hari dilakukan penebaran benih ikan (Gambar 5), sumber benih dalam penyuluhan ini adalah benih hasil pemijahan kelompok POKDAKAN Dolphin Farm. Ukuran benih yang ditebarkan memiliki kisaran panjang dan berat rata-rata berturut-turut yaitu 3-5 $\mathrm{cm}$ dan berat 7,5-9 gram dengan padat tebar benih 1 ekor/L. Penebaran benih dilakukan pada pagi hari dan diaklimatisasi terlebih dahulu selama 1-2 jam untuk menyesuaikan suhu wadah pemeliharaan (Avnimelech, 2009; Putra et al., 2017). Pemberian pakan dilakukan 3 kali sehari, yaitu pada pagi hari sekitar pukul 08.00, siang pukul 13.00 dan sore pukul 17.00 WIB. Pakan yang diberi berupa pellet dengan kandungan protein tinggi sekitar 30-40\% yang diberikan setiap hari sebanyak 3-5\% dari berat ikan yang dipelihara (Adelina et al., 2015).

\section{Evaluasi}

Hasil evaluasi proses menunjukkan selama praktek seluruh peserta penyuluhan terlibat secara langsung pada setiap tahap yang dikerjakan dan terlihat bersemangat dalam mengikuti setiap tahapan kegiatan yang dilakukan. Setelah praktek terlihat seluruh peserta sudah bias melakukan teknik yang diberikan secara mandiri.

Hasil evaluasi peningkatan pengetahuan terhadap 23 orang peserta penyuluhan menunjukkan 20 orang $(86,96 \%)$ belum pernah mengenal tentang aplikasi probiotik pada media budidaya, sedangkan 2 orang $(8,70 \%)$ telah mengetahui tentang aplikasi probiotik serta 1 orang $(4,34 \%)$ telah mengaplikasikannya pada kolam budidaya ikan lele. Setelah mengikuti kegiatan pelatihan ini terjadi peningkatan pengetahuan tentang aplikasi probiotik ini sebesar $86,96 \%$. Sementara itu 22 orang peserta telah memahami tentang dosis dan frekuensi pemberian pakan, dan seluruh peserta telah mengetahui bagaimana kriteria benih ikan yang sehat. Penilaian mitra terhadap pelaksanaan kegiatan ini adalah: 52,17 sangat setuju aplikasi probiotik ini dapat dilakukan secara mandiri, 52,17\% dapat meningkatkan kualitas air; 60,87\% dapat menjadi alternative matapencaharian dan $65,22 \%$ dapat mempercepat masa pemeliharaan, sehingga berpotensi untuk dikembangkan kedepannya.

\section{KESIMPULAN}

Aplikasi probiotik pada media budidaya ikan lele di KelurahanTangkerang Utara dapat diterima dengan baik. Hasil evaluasi yang dilakukan sebelum dan setelah dilakukannya kegiatan penyuluhan ada peningkatan pengetahuan dan keterampilan pembudidaya ikan di Kelurahan ini. Peserta umumnya sangat setuju dengan pelaksanaan kegiatan ini. Peningkatan pengetahuan dan keterampilan pembudidaya ikan dalam aplikasi probiotilk pada pembesaran ikan lele dapat menjadi bekal agar kegiatan budidaya ini dapat terus berlanjut, dan KelurahanTangkerang Utara ini dapat menjadi daerah percontohan untuk daerah sekitarnya beberapa tahun ke depan. Kendala yang dihadapi TIM desa binaan adalah sulit untuk melakukan alih tekhnologi secara tatap muka terhadap mitra karena adanya pandemi COVID 19, sehingga alih tekhnologi tidak berjalan secara maksimal.

\section{UCAPAN TERIMA KASIH}

Ucapan terima kasih dihaturkan kepada Lembaga Penelitian dan Pengabdian kepada Masyarakat Universitas Riau selaku pemberi dana, Lurah Tangkerang Utara, Ketua Kelompok Perikanan Cahaya Utara Mandiri Burhan Budi, Ketua Dolphin Farm Suhendra, mahasiswa kukerta terintegrasi, Rudi Alfinda, S.Pi. dan Dr. Nur Asiah, S.Pi., M.Si. yang telah berkontribusi besar dalam pelaksanaan kegiatan ini. 


\section{DAFTAR PUSTAKA}

Adelina, I. Boer dan I. Suharman. 2015. Pakan Ikan Budidaya dan Analisis Formulasi. UNRI Press. 102 hlm.

Avnimelech, Y. 2009. Biofloc technology. A practical guide book. The World Aquaculture Society. https://www.researchgate.net/publication/308052605. diakses 20 Februari 2020.

Badan Pusat Statistik Kota Pekanbaru. 2018. Kecamatan Bukit Raya Dalam Angka. CV. M.N. Grafika. 79 hal. https://www.scribd.com/document/424535886/ Kecamatan-Tenayan-Raya-Dalam-Angka-2018. diakses 8 Februari 2020.

Irianto, A. 2003. Probiotik Akuakultur. Yogyakarta: Gadjah Mada University Press. 125 hlm

Lhaksmanan, R dan Soundarapandian, P. 2008. Effect of commercial probiotik on large scale culture of black tiger shrimp Panaeus monodon (Fabricius). Research J. Microbiology, 3(3), 198-203.

Mansyur, A, dan A.M. Tangko. 2008. Probiotik: Pemanfaatan Untuk Makanan Ikan Berkualitas Rendah. Media Akuakultur, 2(2), 145-49. http://dx.doi.org/10.15578/ma.3.2.2008.145-149

Pamukas N. A., Syafriadiman, I. Lukistyowati, Efriyeldi, Feliatra, Mulyadi, A. D. Syakti, M. Fauzi and Windarti. 2020. Types and abundance of plankton in the hybrid tilapia brackish water culture media enriched with mixed booster(plankton, aqua enzyme and amino liquid). AACL Bioflux, 13(2), 1198-1210. http://www.bioflux.com.ro/docs/2020.1198-1210.pdf

Poernomo, A. 2004. Teknologi Probiotik Untuk Mengatasi Permasalahan Tambak Udang dan Budidaya. Makalah disajikan dalam Simposium Pengembangan Ilmu dan InovasiTeknologi dalam Budidaya. Semarang. 27-29 Januari. 24 hlm.

Putra, I., M. Fauzi, Rusliadi, U.M. Tang, and Z.A. Muchlisin. 2017. Growth performance and feed utilization of African catfish Clarias gariepinus fed a commercial diet and reared in the biofloc system enhanced with probiotic [version 1; referees: 2 approved]. F1000 Research, 6(1545), 1-7. https://doi.org/10.12688/f1000research.12438.1

Putra, I., I. Effendi, I.Lukistyowati, U. M. Tang, M. Fauzi, I. Suharman and Z. A. Muchlisin. 2020. Effect of different biofloc starters on ammonia, nitrate, and nitrite concentrations in the cultured tilapia Oreochromis niloticus system. F1000 Research, 9(293), 1-13. https://doi.org/10.12688/f1000research.22977.3

Rusliadi, I. Putra, M. Fauzi, N.A.Pamukas, dan H. Masjudi. 2018. Pengembangan mata pencaharian alternatif bagi nelayan melalui kegiatan budidaya ikan dengan teknologi bioflok di Kampung Sungai Kayu Ara. Riau Journal of Empowerment, 1(2), 61-65. https://doi.org/10.31258/raje.1.2.8 